\title{
ANALISIS KUALITAS LAYANAN TERHADAP KEPUASAN KONSUMEN PT. KERETA API INDONESIA (Studi Kasus Stasiun Pariaman)
}

\author{
Noval Prabowo, Febsri Susanti \\ Sekolah Tinggi Ilmu Ekonomi "KBP" \\ febsrisusanti@akbpstie.ac.id \\ novalprabowo23@gmail.com
}

\begin{abstract}
This study aims to menganilisis how much influence on the Service Quality Customer Satisfaction PT. KAI in Pariaman Station. After knowing the relevant literature review, this study set out important variables that allegedly affect Customer Satisfaction ie Reliability (X1), Responsiveness (X2), Assurance (X3), Empathy (X4) and Tangible (X5). Quantitative analysis includes: Validity and reliability, Descriptive Analysis, Classical Assumption Test, Analysis of linear regression, hypothesis testing via t test and $F$ test, and analysis of determination (R2). Qualitative analysis is the interpretation of the data obtained in the study and the results of data processing that has been carried out by giving a description and explanation. The data that have met Validity, Reliability and Test Test Classical Assumption processed resulting regression equation as follows: $Y$ $=8083-0240 X 1+X 20083+0307+0888 X 3 X 5+X 4+0309+e$, Where Customer Satisfaction variable $(Y)$, the variable Reliability (X1), Responsiveness (X2), Assurance (X3), Empathy (X4) and Tangible (X5). Hypothesis testing using $t$ tests showed that the Reliability (X1), Responsiveness (X2), Assurance (X3), Empathy (X4) and Tangible (X5) studied had a significant influence on customer satisfaction. Then through the $F$ test showed that the variables Reliability (X1), Responsiveness (X2), Assurance (X3), Empathy (X4) and Tangible (X5) simultaneously influence consumer satisfaction. Adjusted Figures Rsquare that is equal to 0375 which showed that between Reliability, Responsiveness, Assurance, Empathy and Tangible able to explain jointly to Consumer Satisfaction PT. KAI in Pariaman stations by 37.5\%, while the rest influenced by other variables not included in this study.
\end{abstract}

Keywords: Customer Satisfaction, Reliability, responsiveness, Assurance, Empathy and Tangible

\section{PENDAHULUAN}

Pemasaran adalah salah satu strategi bisnis yang mengidentifikasikan kebutuhan dan keinginan pelanggan (Customer), menentukan pasar sasaran dan juga mengupayakan untuk melayani pelanggan dengan baik. Dan juga merancang produk dan juga jenis jasa serta program yang tepat untuk melayani pasar sasaran. 
Dan secara garis besar manusia memuaskan kebutuhan dan keinginan mereka yaitu dengan produk baik barang dan jasa. Konsep produk adalah sesuatu yang di tawarkan untuk di diperhatikan, di miliki di gunakan atau di konsumsi yang dapat memuaskan kebutuhan dan keinginan. Jasa adalah aktifitas yang atau manfaat yang dapat di tawarkan yang pada dasarnya tidak berakibat pada kepemilikan apapun (Kotler, 2001; 337). Dalam bisnis jasa produsen dan konsumen harus berinteraksi dengan efektif untuk menciptakan nilai yang superior selama pembelian jasa.

Ada tiga hal yang penting yang menjadi tugas pemasar dalam memasarkan produk Jasa. Salah satu strategi pemasaran produk jasa yaitu dengan kualitas pelayanan (Kotler, 1997; 90). Kualitas jasa adalah tingkat keunggulan yang diharapkan dan pengendalian atas keunggulan yang diharapkan tersebut untuk memenuhi keinginan pelanggan. Pada pinsipnya kualitas jasa berfokus pada upaya pemenuhan kebutuhan dan keinginan pelanggan, serta ketepatan penyampaiannya untuk mengimbangi harapan pelanggan sehingga jasa tersebut dapat memuaskan pelanggan.

Salah satu cara untuk menciptakan kepuasan pelanggan yaitu melalui peningkatan kualitas, karena pelanggan adalah fokus utama ketika kita mengungkap kepuasan dan kualitas jasa. Persoalan jasa merupakan harga yang harus dibayar oleh perusahaan yang ingin tetap bertahan dalam bisnisnya (Lopiyoadi dan Hamdani, 2006; 168). Dan sekarang hampir semua perusahaan dapat menghasilkan kualitas jasa yang sama dengan ditetapkannya ISO 9001. Kualitas menurut ISO 9000 adalah "degree to which asset of inherent characteristics fulfills requirements" (derajat yang dicapai oleh karakteristik yang inheren dalam memenuhi persyaratan). Persyaratan dalam hal ini adalah "need expectation that is started, generally implied or obligatory" (yaitu kebutuhan atau harapan yang dinyatakan, biasanya tersirat atau wajib). Dengan kata lain terdapat 2 faktor utama yakni jasa yang diharapkan (expected service) dan jasa yang dipersepsikan (perceived service).

Kualitas pelayanan yang banyak dijadikan acuan dalam riset pemasaran adalah model SERVQUAL (service quality) yang dikembangkan oleh Parasuraman, Zeithmal, dan Berry. Dalam SERVQUAL ada lima dimensi kualitas yaitu berwujud (tangible), keandalan (reliability), ketanggapan (responsiveness), jaminan dan kepastian (assurance), serta empati (empathy). (Lopiyoadi dan Hamdani, 2006; 182).

Jika perusahaan dapat memenuhi kepuasan konsumen maka akan timbul suatu loyalitas. Kepuasan konsumen adalah tingkatan dimana anggapan kinerja (perceived performance) produk akan sesuai dengan harapan seorang pembeli. Bila kinerja produk lebih rendah dibandingkan dengan harapan pelanggan, maka ia tidak puas. Tetapi bila kinerja sesuai dengan harapan atau melebihi harapan pelanggan maka pembelinya akan puas atau sangat gembira (Kotler dan Amstrong, 2001; 10).

Kualitas memiliki hubungan yang erat dengan kepuasan pelanggan. Kualitas memberikan dorongan kepada pelanggan untuk menjalin ikatan hubungan yang kuat dengan perusahaan, sedangkan kepuasan adalah respon pemenuhan dari konsumen. Kepuasan adalah hasil dari penilaian dari konsumen bahwa produk atau pelayanan telah memberikan tingkat kenikmatan dimana tingkat pemenuhan ini bisa lebih atau kurang. Kepuasan pelanggan ditentukan 
oleh persepsi pelanggan atas performance produk atau jasa dalam memenuhi harapan pelanggan. Pelanggan merasa puas apabila harapannya terpenuhi atau akan sangat puas jika harapan pelanggan terlampaui (Fandy Tjiptono, 2002).

Dalam kepuasan ada beberapa indikator yang dapat digunakan sebagai alat ukur: kepuasan general atau keseluruhan (overall satisfaction), dimensi kepuasan, konfirmasi harapan (confirmation of expectation), minat pembelian ulang (repurchase intent), kesediaan untuk merekomendasi (willingness to recommend), ketidakpuasan pelanggan (customer dissatisfation) (Tjiptono, 2004; 366).

PT. Kereta Api Indonesia (KAI) merupakan salah satu perusahaan yang bergerak di bidang jasa pelayanan angkutan darat. Stasiun Pariaman merupakan salah satu daerah operasional dari PT. KAI DIVRE II. Wilayah Pariaman merupakan daerah yang potensial dari segi pariwisata. Maka PT. KAI bekerja sama dengan Pemerintah Kota Padang Pariaman dan Pemerintah Kota Padang, untuk lebih memperhatikan kualitas pelayanan terhadap masyarakat pengguna jasa Transportasi Kereta Api dalam bentuk PSO (Public Service Oblication). Tetapi dalam kenyataannya di lapangan masih banyak kesenjangan yang berkaitan dengan kualitas pelayanan dan kepuasan penumpang. Hal tersebut terbukti banyaknya penumpang Kereta Api yang kesulitan mendapatkan tiket dan sering juga penumpang yang telah memiliki tiket ketinggalan Kereta Api.

Tiket Kereta Api ini menyediakan 2 macam tiket yaitu tiket duduk dan tiket berdiri. Tiket yang disediakan oleh PT. Kereta Api ini adalah sebanyak 1.504 tiket (tiket duduk) ditambah 752 tiket (tiket berdiri) dalam sehari untuk 4 kali keberangkatan. Tiket berdiri tersedia apabila tiket duduk telah habis. Untuk keberangkatan Kereta Api pertama menyediakan 276 tiket duduk dan 138 tiket berdiri. Untuk keberangkatan Kereta Api kedua menyediakan 476 tiket duduk dan 238 tiket berdiri. Untuk keberangkatan Kereta Api yang ketiga menyediakan 276 tiket duduk dan 138 tiket berdiri. Dan untuk keberangkatan Kereta Api yang terakhir menyediakan 476 tiket duduk dan 238 tiket berdiri.

Dilihat dari segi reliability, PT. KAI stasiun Pariaman kurang mampu memberikan layanan yang akurat. Pengguna jasa kadang menunggu lama diakibatkan keterlambatan kereta yang mana lama keterlambatan kereta api ini sampai 20 menit dari jadwal yang seharusnya. Dilihat dari segi Responsiveness, para karyawan kurang menginformasikan kepada para pengguna jasa Kereta Api. Dimana saat pengguna jasa Kereta Api yang ingin membeli tiket, akan tetapi tidak mengetahui tiket yang akan dibeli untuk keberangkatan yang keberapa. Dari segi Tangible, tanggapan penumpang tentang pelayanan PT. KAI menilai kebersihan memang bisa di unggulkan akan tetapi dari segi kenyamanan penumpang untuk mendapatkan tiket lumayan sulit contohnya pada saat hari sabtu dan minggu dan hari libur Nasional, penumpang harus menunggu lama untuk mendapatkan tiket dikarenakan antrian yang sangat panjang dan loket yang dioperasikan hanya satu dari dua loket yang ada, satu antrian penumpang hanya bisa mendapatkan maksimal 4 tiket.

Stasiun Pariaman merupakan salah satu bagian dari PT. KAI yaitu daerah operasional Padang. PT. KAI merupakan BUMN yang monopoli, jadi kebijakannya ditentukan pusat seperti layanan yang diberikan kepada konsumen bersifat sentral. Stasiun Pariaman merupakan daerah yang mempunyai potensi yang besar dalam bisnis Kereta Api. 


\section{LANDASAN TEORI DAN HIPOTESIS Pengertian Pemasaran}

Pemasaran adalah proses pemberian kepuasan kepada konsumen untuk mendapatkan laba. Dua sasaran pemasaran yang utama adalah menarik konsumen baru dengan menjanjikan nilai yang unggul dan mempertahankan konsumen saat ini dengan memberikan kepuasan (Kotler dan Amstrong, 2001; 5).

Menurut Evant dan Bermant (dalam Tjiptono, 2004; 2) pemasaran adalah pengantisipasian, pengelolaan, dan pemuasan permintaan melalui proses penukaran. Menurut Miller dan Layton (dalam Tjiptono, 2004; 2) pemasaran adalah sistem total aktifitas bisnis yang dirancang untuk merencanakan, menetapkan harga, mempromosikan dan mendistribusikan produk, jasa dan gagasan yang mampu memuaskan keinginan pasar sasaran dalam rangka mencapai tujuan organisasional. Menurut Carman (dalam Tjiptono, 2004; 2) pemasaran adalah dimana struktur permintaan terhadap produk dan jasa diantisipasi atau diperluas dan dipuaskan melalui konsepsi, promosi, distribusi dan penukaran barang.

Dari beberapa pendapat diatas dapatlah dimengerti bahwa pemasaran (Marketing) merupakan suatu sistem menyeluruh dari kegiatan usaha. Untuk merencanakan, menentukan harga, mempromosikan dan mendistribusikan barang dan jasa untuk memuaskan kebutuhan konsumen atau pemakai.

\section{Pengertian Jasa}

Menurut Kotler (dalam Tjiptono, 2004; 6) jasa adalah setiap tindakan atau perbuatan yang ditawarkan oleh salah satu pihak ke pihak lain yang secara prinsip intangible (tidak berwujud) dan tidak menyebabkan perpindahan kepemilikan apapun. Produksi jasa bias berhubungan produk fisik atau tidak. Pengertian kedua Jasa adalah semua aktifitas ekonomi yang hasilnya bukan berbentuk produk fisik atau konstruksi, yang umumnya dihasilkan dan dikonsumsi secara bersamaan serta memberikan nilai tambah konsumen (Lopiyoadi dan Hamdani, 2006; 5).

Menurut Gronroos (dalam Tjiptono dan Chandra, 2005; 11) jasa adalah proses yang terdiri dari serangkaian aktifitas intangible yang biasanya (namun tidak selalu) terjadi interaksi pelanggan dan karyawan jasa dan atau sumber daya fisik atau barang dan atau sistem penyedia jasa, yang disediakan sebagai solusi atas masalah pelanggan.

Jadi, dapat disimpulkan bahwa jasa atau layanan merupakan suatu kinerja yang tidak berwujud, lebih dapat dirasakan dan tidak mengakibatkan adanya perpindahan kepemilikan barang dalam proses mengkonsumsi jasa atau layanan seperti yang berlaku pada produk yang berupa barang. Sehingga kesuksesan perusahaan jasa atau layanan akan sangat tergantung pada penilaian pelanggan terhadap kinerja yang ditawarkan oleh pihak perusahaan sebagai produsen.

\section{Kualitas Layanan}

Menurut Parasuraman, Zeithaml dan Berry (dalam Tjiptono dan Chandra, 2005; 133) menyatakan bahwa ada lima dimensi kualitas layanan yang merupakan penyederhanaan dari sepuluh dimensi kualitas pelayanan yaitu:

\section{a. Keandalan (Reliability)}

Memiliki dua aspek utama yaitu konsistensi kinerja (performance) dan sifat dapat dipercaya (dependability). Reliability Berkaitan dengan kemampuan perusahaan memberikan layanan yang akurat sejak pertama kali tanpa 
melakukan kesalahan apapun dan menyampaikan jasanya sesuai dengan waktu yang telah disepakati.

b. Keresponsifan (Responsiveness)

Berkenaan dengan kesediaan dan kemampuan para karyawan untuk membantu para pelanggan dan merespon permintaan mereka, serta menginformasikan kapan jasa akan diberikan dan kemudian memberikan jasa secara cepat.

c. Jaminan (Assurance)

Yakni perilaku para karyawan mampu menimbulkan kepercayaan pelanggan terhadap perusahaan dan perusahaan tersebut dapat menciptakan rasa aman bagi para pelanggannya. Jaminan juga berarti bahwa para karyawan selalu bersikap sopan dan menguasai pengetahuan dan ketrampilan yang dibutuhkan untuk menangani pertanyaan atau masalah pelanggan.

d. Empati (Empathy)

Berarti perusahaan memahami masalah para pelanggannya dan bertindak demi keinginan pelanggan, serta memberikan perhatian personal kepada para pelanggan dan memiliki jam operasi yang nyaman.

e. Berwujud (Tangible)

Berkenaan dengan daya tarik fasilitas fisik, perlengkapan, dan material yang digunakan perusahaan, serta panampilan karyawan.

\section{Kepuasan Konsumen}

Kata kepuasan (satisfaction) berasal dari bahasa latin Satis (cukup baik, memadai) dan Facio (melakukan atau membuat). Jadi bisa diartikan upaya pemenuhan sesuatu atau membuat sesuatu memadai (Tjiptono dan Chandra, 2005; 195). Pengertian kepuasan konsumen adalah tingkatan dimana anggapan kinerja (perceived performance) produk akan sesuai dengan harapan seorang pembeli. Bila kinerja produk lebih rendah dibandingkan dengan harapan pelanggan, maka ia tidak puas. Tetapi bila kinerja sesuai dengan harapan atau melebihi harapan pelanggan maka pembelinya akan puas, atau sangat gembira (Kotler dan Amstrong, 2001; 10).

Menurut Howard dan Sheth (dalam Tjiptono, 2004; 349) kepuasan konsumen adalah situasi kognitif pembeli berkenaan dengan kesepadanan atau ketidaksepadanan antara hasil yang didapatkan dibandingkan dengan pengorbanan yang dilakukan. Menurut Westbrook dan Reilly (dalam Tjiptono, 2004; 349) kepuasan konsumen adalah respon emosional terhadap pengalamanpengalaman berkaitan dengan produk atau jasa tertentu yang dibeli, gerai ritel, atau bahkan pola perilaku (seperti perilaku berbelanja dan perilaku pembeli), serta pasar secara keseluruhan.

Menurut Wilkie (dalam Tjiptono, 2004; 249) kepuasan konsumen adalah tanggapan emosional pada evaluasi terhadap pengalaman konsumsi terhadap produk atau jasa. Menurut Widyaratna $(2001 ; 89)$ ada dua macam kepuasan yang dirasakan oleh pelanggan:

1) Kepuasan Fungsional, merupakan kepuasan yang diperoleh dari fungsi atau pemakaian suatu produk.

2) Kepuasan Psikologikal, merupakan kepuasan yang diperoleh dari atribut yang bersifat tak berwujud atas pembelian produk.

Kepuasan pelanggan ditentukan oleh persepsi pelanggan atas performance produk atau jasa dalam memenuhi harapan pelanggan. Pelanggan merasa puas 
apabila harapannya terpenuhi atau akan sangat puas jika harapan pelanggan terlampaui (Fandy Tjiptono, 2002). Pelanggan yang puas adalah pelanggan yang akan berbagi kepuasan dengan produsen atau penyedia jasa. Bahkan Oleh karena itu, baik pelanggan maupun produsen, akan sama-sama diuntungkan apabila kepuasan terjadi. Dengan melihat hubungan ini, jelaslah bahwa kepuasan pelanggan haruslah menjadi salah satu tujuan dari setiap perusahaan.

Dari beberapa uraian definisi mengenai kepuasan, maka secara umum kepuasan dapat diartikan sebagai suatu perbandingan antara layanan atau hasil yang diterima konsumen dengan harapan konsumen. Dimana layanan atau hasil yang diterima itu paling tidak harus sama dengan harapan konsumen, atau bahkan melebihinya.

Badan usaha dapat mengetahui kepuasan dari para konsumennya melalui umpan balik yang diberikan oleh konsumen kepada badan usaha tersebut sehingga dapat menjadi masukan bagi keperluan pengembangan dan implementasi serta peningkatan kepuasan pelanggan.

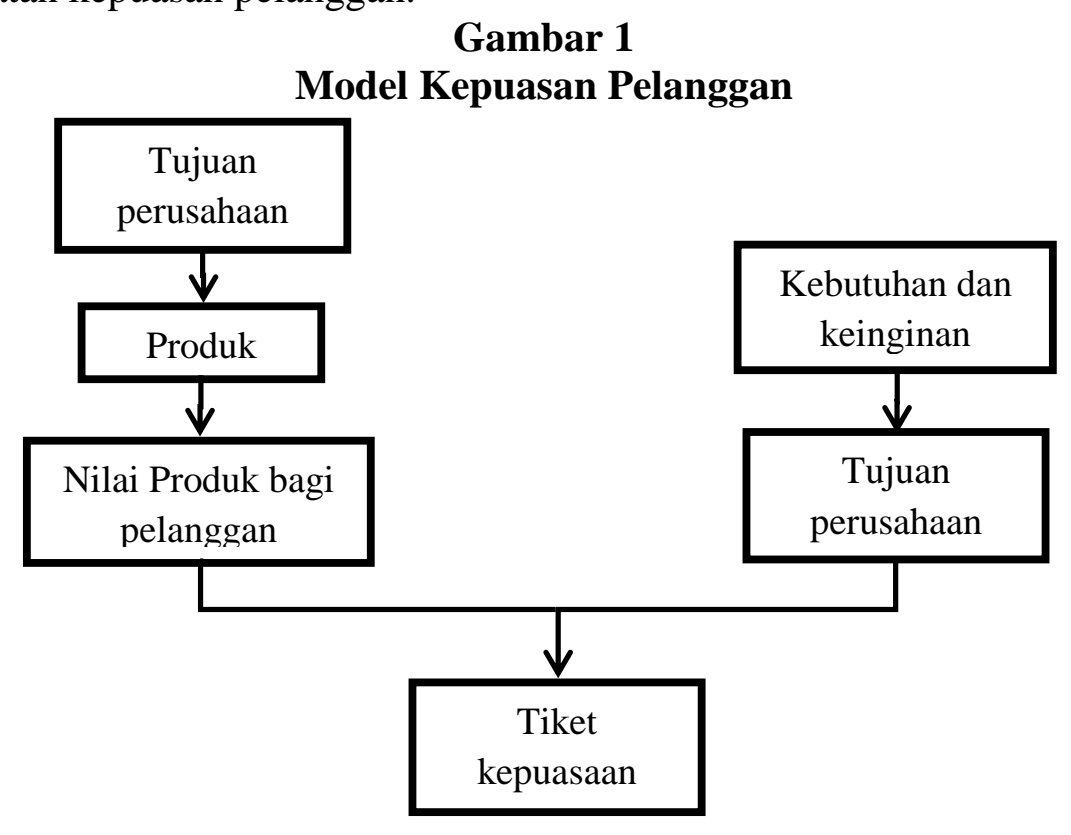

\section{Harapan Konsumen}

Sumber : Fandy Tjiptono, Strategi pemasaran, Edisi II, p 25

Harapan pelanggan diyakini mempunyai peranan yang besar dalam evaluasi kualitas produk (Barang dan Jasa) dan kepuasan pelanggan. Harapan pelanggan pada dasarnya ada hubungan yang erat antara penentuan kualitas dan kepuasaan pelanggan (Tjiptono 1997; 28).

Ekspektasi pelanggan atau customer expectation selalu ada karena empat hal: Individual Need atau kebutuhan perseorangan menjadi factor yang penting artinya kalau pelanggan anda memang sudah punya tuntutan yang tinggi, maka ekspektasinya sudah pasti tinggi juga. Word of mouth pelanggan anda bisa punya harapan tertentu karena cerita orang lain. Cerita orang lain sering dianggap sebagai referensi. Past experience atau pengalaman masa lalu. Orang yang sudah punya pengalaman baik dimasa lalu akan dapat menerima pelayanan minimal sama dengan yang dulu, kalau tidak dia akan kecewa. External communication atau komunikasi eksternal adalah suatu usaha perusahaan untuk berjanji sesuatu kepada pelanggan dalam rangka menarik pelanggan (Kertajaya, 2004; 223). 
Dalam evaluasinya pelanggan akan menggunakan harapannya sebagai standar atau acuan dalam menilai kinerja produk atau jasa tersebut. Dengan demikian, harapan pelangganlah yang melatar belakangi tercapainya kesepakatan mengenai sifat harapan yang spesifik. Jumlah standar yang digunakan maupun sumber harapan dapat dinilai berbeda oleh pelanggannya.

\section{Faktor Penentu Kepuasan Konsumen}

Faktor-faktor Kepuasan Konsumen Reliability (keandalan), Kepuasan to and remedy of problems (respon dan cara pemecahan masalah), Sales experience (pengalaman karyawan), convenience of acquisition (kemudahan dan kenyamanan).

1) Reliability (keandalan)

Reliability merupakan kemampuan dari suatu perusahaan untuk menghasilkan produk sesuai dengan apa yang dijanjikan oleh perusahaan. Diantaranya adalah kecepatan dan ketepatan karyawan.

2) Kepuasan to and remedy of problems (respon dan cara pemecahan masalah) Kepuasan to and remedy of problems merupkan sikap dari karyawan PT KAI dalam menanggapi keluhan serta masalah yang dihadapi oleh pelanggan.

3) Sales experience (pengalaman karyawan)

Sales experience merupakan semua hubungan antara pelanggan dengan karyawan PT KAI khususnya dalam hal komunikasi yang berhubungan dengan pelayanan yaitu membantu memberikan pendapat dan saran kepada pelanggan yang akan memakai layanannya.

4) Convenience of acquisition (kemudahan dan kenyamanan)

Convenience of acquisition merupakan segala kemudahan dan kenyamanan yang diberikan oleh perusahaan kepada pelanggan yang akan memakai layanan PT KAI. (Musanto, 2004; 127).

Menurut Tjiptono, $(2004 ; 366)$ ada 6 aspek penting yang perlu ditelaah dalam kerangka pengukuran kepuasan pelanggan yakni: 1)kepuasan general atau keseluruhan (overall satisfaction), 2)konfirmasi harapan (confirmation of expectation) yakni tingkat kinerja dengan ekspektasi, 3)Dimensi kepuasan pelanggan, 4)minat pembelian ulang (repurchase intent), 5)kesediaan untuk merekomendasi (willingness to recommend), 6)ketidakpuasan pelanggan (customer dissatisfaction).

\section{Hipotesis}

Hipotesis merupakan jawaban yang bersifat sementara terhadap suatu permasalahan penelitian sampai terbukti melalui data yang terkumpul (Arikunto, 1998; 67). Pada penelitian ini hipotesis yang akan diuji adalah sebagai berikut:

H1: Reliability (keandalan) berpengaruh positif terhadap Kepuasan Konsumen PT. Kereta Api di Pariaman.

$\mathrm{H}$ 2: Responsiveness (keresponsifan) berpengaruh positif terhadap Kepuasan Konsumen PT. Kereta Api di Pariaman.

H3: Assurance (jaminan) berpengaruh positif terhadap Kepuasan Konsumen PT. Kereta Api di Pariaman.

H4: Empathy (empati) berpengaruh positif terhadap Kepuasan Konsumen PT. Kereta Api di Pariaman.

H5: Tangible (berwujud) berpengaruh positif terhadap Kepuasan Konsumen PT. Kereta Api Pariaman. 


\section{METODE PENELITIAN}

Jenis penelitian yang dipakai adalah penelitian kuantitatif, penelitian kuantitatif mengukur data kuantitatif dan statistik objektif melalui perhitungan ilmiah berasal dari sampel orang-orang atau penduduk yang diminta menjawab atas sejumlah pertanyaan survei untuk menentukan frekuensi dan persentase, Teknik pengambilan sampel pada umumnya dilakukan secara random, pengumpulan data menggunakan instrumen penelitian, analisa data bersifat kuantitatif / statistik dengan tujuan untuk menguji hipotesis yang ditetapkan (Wikipedia)

\section{HASIL DAN PEMBAHASAN}

Hasil analisis yang telah dilakukan dalam penelitian ini sudah memenuhi uji persyaratan analisis regresi linear berganda. Data yang dikumpulkan melalui kuesioner yang disebarkan kepada responden telah diuji validitas dan realiabilitasnya sehingga dapat dilanjutkan pada pengujian asumsi klasik yang terdiri dari uji normalitas, uji asumsi non multikolinearitas dan uji asumsi klasik non heteroskesdasitas.

\section{Pengaruh Signifikansi Simultan}

Hasil pengujian hipotesis menunjukan bahwa adanya pengaruh secara simulutan antara $\left(\mathrm{X}_{1}\right)$ Reliability, $\left(\mathrm{X}_{2}\right)$ Responsiveness, $\left(\mathrm{X}_{3}\right)$ Assurance, $\left(\mathrm{X}_{4}\right)$ Empathy dan $\left(\mathrm{X}_{5}\right)$ Tangible terhadap Kepuasan Konsumen. Hal ini menunjukan bahwa kelima variabel independen tersebut secara bersama-sama membuktikan bahwa Kepuasan Konsumen dipengaruhi oleh $\left(\mathrm{X}_{1}\right)$ Reliability, $\left(\mathrm{X}_{2}\right)$ Responsiveness, $\left(\mathrm{X}_{3}\right)$ Assurance, $\left(\mathrm{X}_{4}\right)$ Empathy dan $\left(\mathrm{X}_{5}\right)$ Tangible.

\begin{tabular}{|l|l|l|}
\hline Hipotesis & Nilai & Keputusan \\
\hline $\mathrm{H}_{0}: \beta_{\mathrm{i}}=0$ (terdapat pengaruh yang & $\mathrm{F}=13.494$ & $\mathrm{H}_{0}$ ditolak, \\
tidak signifikan antara variabel $\mathrm{X}_{1}$, & $\mathrm{Sig}=0.000$ & $\mathrm{H}_{\mathrm{a}}$ diterima \\
$\mathrm{X}_{2}, \mathrm{X}_{3}, \mathrm{X}_{4}$ dan $\mathrm{X}_{5}$ terhadap variabel & $\mathrm{F}_{\text {tabel }}=2.306$ & \\
$\mathrm{Y})$ & & \\
$\mathrm{H}_{\mathrm{a}}: \beta_{\mathrm{i}} \neq 0$ (terdapat pengaruh yang & & \\
signifikan antara variabel $\mathrm{X}_{1}, \mathrm{X}_{2}, \mathrm{X}_{3}$, & & \\
$\mathrm{X}_{4}$ dan $\mathrm{X}_{5}$ terhadap variabel $\left.\mathrm{Y}\right), \alpha=$ & & \\
0.05 & & \\
\hline
\end{tabular}

\section{Pengaruh Signifikansi Parsial}

Hasil pengujian hipotesis menunjukan bahwa variabel Reliability $\left(\mathrm{X}_{1}\right)$, Responsiveness $\left(\mathrm{X}_{2}\right)$ dan Assurance $\left(\mathrm{X}_{3}\right)$ memiliki nilai signifikan $\mathrm{t}$ yang lebih besar dari Sig.a (0.05) sehingga dapat dikatakan bahwa variabel tersebut memiliki pengaruh yang tidak signifikan secara parsial terhadap Kepuasan Konsumen. Empathy $\left(\mathrm{X}_{4}\right)$ dan Tangible $\left(\mathrm{X}_{5}\right)$ memiliki nilai signifikan t yang lebih besar dari Sig.a $(0,05)$ sehingga dapat dikatakan bahwa variabel tersebut memiliki pengaruh yang signifikan secara parsial terhadap Kepuasan Konsumen.

\section{Pembahasan Hasil Uji Dominan}

Berdasarkan pada tabel 4.29 tersebut, menunjukan bahwa terdapat pengaruh dominan variabel Empathy $\left(\mathrm{X}_{4}\right)$ adalah variabel yang memiliki koefisien regresi yang paling besar. Artinya, variabel Kepuasan Konsumen (Y) lebih banyak dipengaruhi oleh faktor Empathy $\left(\mathrm{X}_{4}\right)$ dari pada variabel-variabel lainnya Reliability $\left(\mathrm{X}_{1}\right)$, Responsiveness $\left(\mathrm{X}_{2}\right)$, Assurance $\left(\mathrm{X}_{3}\right)$ dan Tangible $\left(\mathrm{X}_{5}\right)$. 
Koefisien yang dimiliki oleh variabel $\mathrm{X}_{4}$ bertanda positif, hal ini yang berarti semakin baik Empathy $\left(\mathrm{X}_{4}\right)$ maka semakin meningkatkan Kepuasan Konsumen (Y).

\begin{tabular}{|c|c|c|c|}
\hline Peringkat & Variabel & Koefisien Beta & Pengaruh \\
\hline 5 & Reliability $\left(\mathrm{X}_{1}\right)$ & 4.992 & Signifikan \\
\hline 4 & Responsiveness $\left(\mathrm{X}_{2}\right)$ & 4.431 & Signifikan \\
\hline 3 & Assurance $\left(\mathrm{X}_{3}\right)$ & 4.505 & Signifikan \\
\hline 1 & Empathy $\left(\mathrm{X}_{4}\right)$ & 7.172 & Signifikan \\
\hline 2 & Tangible $\left(\mathrm{X}_{5}\right)$ & 5.295 & Signifikan \\
\hline
\end{tabular}

\section{Implikasi Variabel Dominan}

Dari hasil penelitian di ketahui bahwa variabel Empathy $\left(\mathrm{X}_{4}\right)$ adalah variabel yang paling dominan diantara variabel-variabel yang lain. Hal ini didasari dengan banyaknya konsumen yang menganggap bahwa faktor terpenting dalam Kepuasan Konsumen adalah empati yaitu perusahaan memahami masalah konsumen dan bertindak demi keinginan konsumen, serta memberikan perhatian personal kepada konsumen.

\section{Hasil Koefisien Determinasi}

Berdasarkan tabel 4.30, dari hasil perhitungan Analisis Regresi Linier Berganda yang telah dilakukan menunjukkan kemampuan model dalam menjelaskan pengaruh variabel independent terhadap variabel dependent adalah besar, hal tersebut dapat dilihat pada nilai Adj. $R$. Square $\left(\mathrm{R}^{2}\right)$ yaitu sebesar 0.375 (37.5\%). Dengan demikian berarti bahwa model regresi yang digunakan mampu menjelaskan pengaruh variabel Reliability $\left(\mathrm{X}_{1}\right)$, Responsiveness $\left(\mathrm{X}_{2}\right)$, Assurance $\left(\mathrm{X}_{3}\right)$, Empathy $\left(\mathrm{X}_{4}\right)$ dan Tangible $\left(\mathrm{X}_{5}\right)$ terhadap Kepuasan Konsumen sebesar $40.5 \%$, sedangkan sisanya sebesar $62.5 \%$ dijelaskan oleh variabel-variabel lain yang tidak termasuk dalam penelitian ini.

\section{Implikasi Hasil Penelitian}

Penelitian ini memberikan pengaruh yang besar dan bermanfaat tentang Kepuasan Konsumen di Stasiun Pariaman dalam penelitian ini menunjukan bahwa faktor yang mempengaruhi Kepuasan Konsumen adalah Reliability, Responsiveness, Assurance, Empathy dan Tangible. Hasil penelitian ini menunjukan bahwa faktor-faktor yang berhubungan dengan Reliability, Responsiveness, Assurance, Empathy dan Tangible harus diperhatikan dengan baik. Peningkatan Reliability, Responsiveness, Assurance, Empathy dan Tangible dalam sektor bisnis dapat berpengaruh pada Kepuasan Konsumen untuk menggunakan jasa Kereta Api yang pada akhirnya meningkat pada pengguna jasa Kereta Api. Dari hasil penelitian ini juga diharapkan dapat memberikan masukan bagi PT. KAI agar memperhatikan faktor-faktor seperti Reliability, Responsiveness, Assurance, Empathy dan Tangible dalam menerapkan dan mengembangkan Kepuasan Konsumen. Guna mewujudkan hal tersebut, maka perusahaan harus mengetahui apa yang menjadi kebutuhan, keinginan serta harapan konsumen. Implikasi penelitian yang sebaiknya dilakukan adalah sebagai berikut:

1) Reliability (Keandalan) berpengaruh signifikan terhadap Kepuasan Konsumen karena nilai $\mathrm{t}$ hitung 4.992 dan nilai signifikansi 0.000 kecil dari 
level of significant 0.05. Layanannya maka Konsumen akan merasa puas akan layanan yang diberikan.

2) Responsiveness (Keresponsifan) berpengaruh signifikan terhadap Kepuasan Konsumen karena nilai $\mathrm{t}$ hitung 4.431 dan nilai signifikansi 0.000 kecil dari level of significant 0.05 .

3) Assurance (Jaminan) berpengaruh signifikan terhadap Kepuasan Konsumen karena nilai $\mathrm{t}$ hitung 4.505 dan nilai signifikansi 0.000 kecil dari level of significant 0.05 .

4) Empathy (Empati) berpengaruh signifikan terhadap Kepuasan Konsumen karena nilai $\mathrm{t}$ hitung 7.172 dan nilai signifikansi 0.000 kecil dari level of significant 0.05 .

5) Tangible (Berwujud) berpengaruh signifikan terhadap Kepuasan Konsumen karena nilai $\mathrm{t}$ hitung 5.295 dan nilai signifikansi 0.000 kecil dari level of significant 0.05 .

\section{KESIMPULAN DAN SARAN \\ Kesimpulan}

Hasil penelitian ini menunjukan bahwa Kualitas Pelayanan yang dipaparkan dalam 5 variabel bebas $\left(\mathrm{X}_{1}\right)$ Reliability, $\left(\mathrm{X}_{2}\right)$ Responsiveness, $\left(\mathrm{X}_{3}\right)$ Assurance, $\left(\mathrm{X}_{4}\right)$ Empathy dan $\left(\mathrm{X}_{5}\right)$ Tangible. Berdasarkan penelitian yang penulis lakukan melalui analisa dan kuesioner yang disebarkan, menunjukan bahwa Reliability $\left(\mathrm{X}_{1}\right)$ berpengaruh positif dan signifikan terhadap Kepuasan Konsumen. Responsiveness $\left(\mathrm{X}_{2}\right)$ berpengaruh positif dan signifikan terhadap Kepuasan Konsumen. Assurance $\left(\mathrm{X}_{3}\right)$ berpengaruh positif dan signifikan terhadap Kepuasan Konsumen. Empathy $\left(\mathrm{X}_{4}\right)$ berpengaruh positif dan signifikan terhadap Kepuasan Konsumen. Tangible $\left(\mathrm{X}_{5}\right)$ berpengaruh positif dan signifikan terhadap Kepuasan Konsumen.

\section{Saran}

Berdasarkan hasil penelitian, didapatkan bahwa para pelanggan merasa puas dengan pelayanan yang diberikan oleh perusahaan, akan tetapi tidak menutup kemungkinan adanya kekurangan-kekurangan dalam memberikan pelayanan kepada pelanggannya. Maka, dapat disampaikan beberapa saran sebagai berikut :

1. Bagi Jurusan Fakultas Ekonomi

Diharapkan Jurusan Manajemen Fakulatas Ekonomi mampu mengembangkan penelitian ini lebih lanjut di masa yang akan datang dan menjadikan penelitian ini sebagai salah satu bahan pustaka untuk menambah pengetahuan bagi yang memerlukan.

2. Bagi PT. KAI Stasiun Pariaman

Variabel Reliability (Keandalan), Responsiveness (Keresponsifan) dan Assurance (Jaminan), Empathy (Empati) dan Tangible (Berwujud) secara dominan mempengaruhi Kepuasan Konsumen, sehingga pihak perusahaan diharapkan dapat mepertahankan dan meningkatkan Kualitas Pelayanan PT. KAI di Stasiun Pariaman.

3. Bagi Peneliti Selanjutnya

Untuk penelitian yang selanjutnya disarankan peneliti melakukan penelitian diluar dari variabel kualitas pelayanan dan mengkaji lebih jauh terhadap 
produk dari perusahaan jasa khususnya jasa Kereta Api Stasiun Pariaman hanya pada kualitas pelayanannya.

\section{DAFTAR PUSTAKA}

Amirullah, 2002. Perilaku Konsumen, Jogyakarta: Graha Ilmu.

Arikunto, Suharsimi. 2002. Prosedur Penelitian: Suatu Pendekatan Praktek. Jakarta. Rineka Cipta.

Aziz, N. (2019). Pengaruh Kualitas Layanan Terhadap Kepuasan Nasabah SMS Banking Pada Bank Nagari Cabang Pembantu RSUP DR M Djamil Padang. https://doi.org/10.17605/OSF.IO/S3JVG

Durianto, Darmadi, Sugiarto, Sitinjak Tony. 2001. Strategi Penakluk Pasar Melalui Riset Ekuitas dan Perilaku Merek. Jakarta. PT. Gramedia Pustaka Utama.

Fernandes, Y. D., \& Marlius, D. (2018). Peranan Customer Service Dalam Meningkatkan Pelayanan Kepada Nasabah Pada PT. Bank Pembangunan Daerah Sumatera Barat Cabang Utama Padang. https://doi.org/10.31227/osf.io/wrh3p

Kartajaya, Hermawan. 2004. Hermawan Kertajaya on Marketing, Jakarta: Gramedia Pustaka Utama.

Kotler, Philip. 1997. Manajemen Pemasaran, Analisis, Perencanaan, Implementasi dan kontrol, jilid 1. Jakarta: PT. Prenhallindo.

Kotler, Philip. 1998. Marketing Management: Analisis, Planing, Implementation and Controling. Jakarta. Salemba Empat.

Lopiyoadi, Rambat dan Hamdani, A. 2006. Manajemen Pemasaran Jasa. Jakarta. Salemba Empat.

Marlius, D. (2018). Loyalitas Nasabah Bank Nagari Syariah Cabang Bukittinggi Dilihat Dari Kualitas Pelayanan. Jurnal Pundi. Volume 1. No. 3. Hal.12-22. https://doi.org/10.31575/jp.v1i3.60

Marlius, D. (2018). Pengaruh Dimensi Kualitas Pelayanan Website Akademik Terhadap Kepuasan Mahasiswa Pada STIE “KBP”. Jurnal Ipteks Terapan. Volume 12. No. 2. Hal. 116-128. http://doi.org/10.22216/jit.2018.v12i2.633

Marlius, D. (2017). Keputusan Pembelian Berdasarkan Faktor Psikologis Dan Bauran Pemasaran Pada PT. Intercom Mobilindo Padang. Jurnal Pundi. Volume 1. No. 1. Hal. 57-66. https://doi.org/10.31575/jp.v1i1.9 
Marlius, D. (2016). Pengaruh Bauran Pemasaran Jasa Terhadap Minat Nasabah Dalam Menabung Pada Bank Nagari Cabang Muaralabuh. https://doi.org/10.31227/osf.io/vdqgx

Mayliza, R. (2019). Pengaruh Citra Perusahaan (Corporate Image) Dan Penanganan Keluhan (Complaint Handling) Terhadap Loyalitas Pelanggan (Loyality) Natasha Skin Care Di Kota Padang. https://doi.org/10.17605/OSF.IO/DF9XJ

Mirawati \& Fernos, J. (2019). Peranan Customer Service Dalam Meningkatkan Pelayanan Terhadap Nasabah Pada Bank Nagari Cabang Siteba Padang. https://doi.org/10.31227/osf.io/cq458

Musanto, Trisno, 2004. Factor Kepuasan Pelanggan dan Loyalitas Pelanggan Studi Kasus Pada cv Advertising Surabaya. Jurnal Manajemen \& Kewirausahaan Vol 6, no 2: 123-136.

Putra, A. M., \& Fernos, J. (2019). Pelaksanaan Pelayanan Prima Terhadap Kepercayaan Nasabah Di PT. Bank Perkreditan Rakyat Jorong Kampung Tangah Pariaman. https://doi.org/10.31227/osf.io/c3fy4

Sari, Endang S. 1993. Audience Research : Pengantar Studi penelitian terhadap pembaca, Pendengar dan pemirsa. Yogyakarta : Andi Winardi.

Singarimbun, Masri dan Effendi, 1989. Metode Penelitian dan Survei. Yogyakarta. LP3ES.

Safitri, R. N., \& Marlius, D. (2017). Penerapan E-Banking Dalam Meningkatkan Jasa Dan Layanan Perbankan Di PT. Bank Rakyat Indonesia Cabang Padang. https://doi.org/10.31227/osf.io/gkv8t

Sugiono, 2001. Metode Penelitian Bisnis, Bandung. PT Alfabeta.

Supranto, J. 1997. Pengukuran Tingkat Kepuasan Pelanggan Untuk Menaikkan Pangsa Pasar. Rineka Cipta.

Susanti, F. W Ekazaputri. (2018). Service Performance Dan Kepuasan Sebagai Moderating Variabel Terhadap Loyalitas Nasabah Pada PT BPR Labuh Gunung Payakumbuh Jurnal Benefita: Ekonomi Pembangunan Manajemen Bisnis Dan Akuntansi. Volume 3. No. 3. Hal. 433444.http://doi.org/10.22216/jbe.v3i3.3472

Tiza, M. F., \& Susanti, F. (2019). Pengaruh Kualitas Pelayanan Terhadap Kepuasan Pelanggan, Studi kasus pada perusahaan JNE Cabang Padang. https://doi.org/10.31227/osf.io/hx87m

Tjiptono, Fandy, dan Chandra, Gregorius , 2005. Service, Quality \& Satisfaction. Yogyakarta: Andy Offset. 